$\xi=$ 园

\title{
Groundwater Level Fluctuation in Response to Climatic Variation and its Geotechnical Implication in Part of Awgu Shale, Central Benue Trough, Nigeria.
}

\author{
Umar, Nuhu Degree $^{1}$ *, Idris, Ibrahim Giza ${ }^{1}$, and Abdullahi, Aliyu Itari ${ }^{1}$ \\ ${ }^{1}$ Department of Geology, Faculty of Physical Sciences, University of Nigeria, Nsukka. \\ *Corresponding authorE-mail:degree.umar@unn.edu.ng
}

\begin{abstract}
The role of climate variation on groundwater level and its geotechnical implication was studied. Static water levels (SWL) and elevations of 57 dug wells and boreholes were measured during dry and wet seasons. The differences between the SWL for dry and wet season was used to establish the depth of groundwater fluctuation, while geophysical investigation was conducted to delineate the subsurface geoelectric layers. This information is vital for groundwater assessment and evaluation, however, this research is biased towards its geotechnical implications. SWL varied between 5.5 - 13 and $2.2-9.2$ meters below sea level (mbsl), while groundwater elevation ranges from 131.8 - 157.2 and 136-160 meters above sea level (masl) for dry and wet seasons respectively. The depth of fluctuation (active zone) lies between $1.1-5.9 \mathrm{mbsl}$. The wells showed a direct rapid response to short term seasonal precipitation attributable to climate variation, which implies a shallow aquifer. Groundwater flows from the northern parts towards the southern parts. Foundations in the study area are underlain by sandy-clays, clays and sands as revealed by geophysical investigations. Engineering structures with shallow foundation may be prone to shrink-swell behavior, and should be laid beyond active zone.
\end{abstract}

Keywords: Climatic Variation; Geotechnical; Giza; Groundwater; Geoelectric Layers.

\section{Introduction}

Groundwater level fluctuation (rise and fall) in response to localized climate change occurs in virtually all arid and semi-arid climatic regions, characterized by wet and dry seasons. The fluctuation in groundwater levels of these regions mostly occurs within the unconfined shallow aquifers. The change in temperature and precipitation influences the recharge of the groundwater aquifers, causing shifts in water table levels in unconfined aquifers (Apaydin, 2009; Changnon et al.1988; and Zektser and Loaiciga, 1993), the influence is not restricted to temperature and precipitation alone, but also over-extraction and vegetation.

Climate variability, being relatively short term compared to climate change, will have greater impact on shallow unconfined aquifer systems, whereas water levels in deeper aquifers can only be influenced by the latter (Apaydin, 2009). Understanding the relationship between the localized climate variation and groundwater level fluctuation within the study area (Giza), will enhanced a better planning and decision making regarding agricultural activities, groundwater abstraction and management; landfill and sewage system design; and designs of engineering structures (dams, roads, and buildings). Given that all engineering structures transmit their load to a considerable depth beneath the surface, the interaction between the structural loads and the underlying soils strata containing water must not be neglected. As such, the depth to water table, groundwater movement, and groundwater level fluctuation assessment should be done prior to designs and constructions.
Most recent research has focused on the effect of groundwater level fluctuation on: well yield (Apaydin, 2009), estimation of aquifer recharge (Sang-ki et al. 2003), groundwater evaluation and management (Alexandra et al. 2015). Umar (2014) delineated the saline water zone and assessed the groundwater quality in Giza and reported that it is suitable for drinking in most parts and unsuitable in some parts. Offodile (2002) studied the occurrence of groundwater in the sedimentary rocks of Nasarawa State and reported that the aquifer of the Awgu Formation has low yield.

However, the impact of seasonal variation on groundwater fluctuation as it affects engineering structures has not been prioritized. It is on this note that this research was necessitated, as it can be applied for many purposes such as agriculture, sanitation or foundation design.

Collison et al. (2000), identified pore water pressure as one of the consequences of climate change on groundwater. According to Bell (2007), understanding of the local geology and groundwater conditions is vital for risk assessment and mitigation, as regards foundation design and stability. Information about water-table position would be useful in understanding the susceptibility of an aquifer to contaminants, groundwater flow direction, as well as the depth at which groundwater may affect engineering structures (Tahir et al. 2016). The aim of this research is to study how seasonal variations affect groundwater level fluctuation; the direction of groundwater flow in wet and dry seasons; and whether or not these fluctuations have effect on foundations of engineering structures. These will be achieved by measuring the static water levels in hand-dug wells and boreholes, measuring their elevations, and taking their coordinates at the peak of wet and dry season respec- 
tively, as well as conducting subsurface geophysical investigations.

\section{Geomorphology and description of study area}

\subsection{Location and accessibility}

The study area (Giza) lies within latitudes $8^{\circ} 11^{\prime}-8^{\circ} 12 \mathrm{~N}$ and longitudes $8^{\circ} 38^{\prime}-8^{\circ} 38^{\prime} 50 \mathrm{E}$ (Fig.4). The area is accessible through both tarred and graded-untarred roads. The main access route being the tarred Lafia-Makurdi road, while the graded-untarred roads include the Kadarko - Giza, Keana - Giza, Giza - Yelwata and Obi Giza roads.

\subsection{Climate and vegetation}

The study area is characterized by a tropical sub-humid climate with two distinct seasons, wet and dry. The wet season lasts from the beginning of May to October, while the dry season is experienced between November and April. The highest amount of rainfall is recorded between May and September (Fig.1). Annual rainfall ranges from $1500 \mathrm{~mm}$ to about $2000 \mathrm{~mm}$. The wettest month, being July and August (Fig.1), while 95\% of rain falls between May to September. Humidity is generally high during the wet season $95 \%$, and drops to about $55 \%$ for the dry season. Temperature is generally high during the day, particularly between the month of March and April. The mean monthly temperature ranges between $25^{\circ} \mathrm{c}-34^{\circ} \mathrm{c}$ (Fig.2), with the coolest month being December and January. The area falls within forest savannah zone of Nigeria, rich in deep fertile alluvial soils, which are enriched with abundant forest biomass.

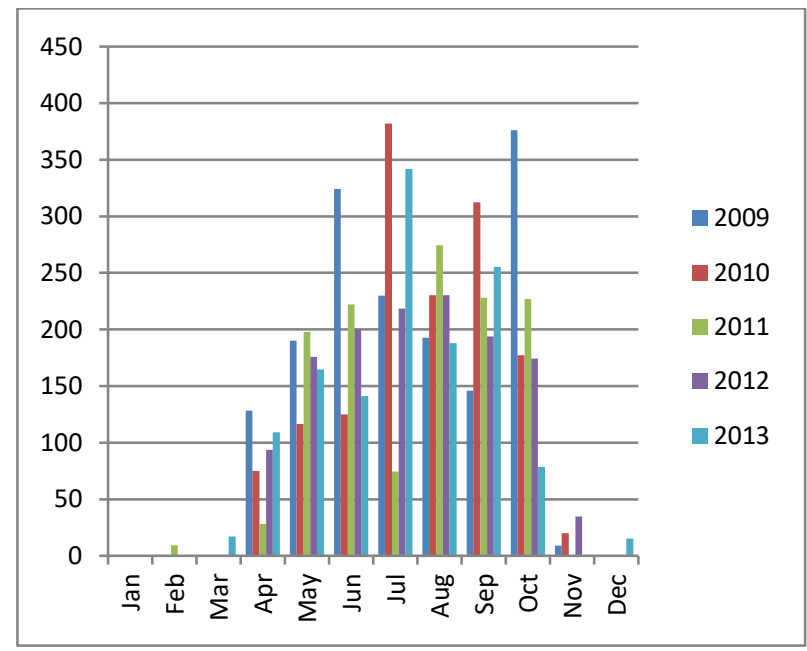

Fig. 1: Mean Annual Rainfall From 2009 - 2013 (NIMET Lafia).

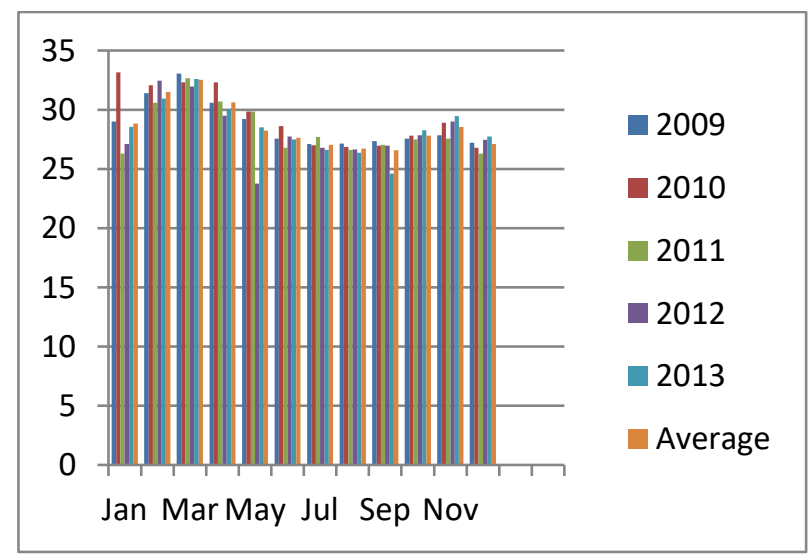

Fig. 2: Mean Annual Temperature From 2009 - 2013 (NIMET Lafia).

\subsection{Relief and drainage}

Generally, the study area elevation ranges from 139 to 165 meters above mean sea level. The area has a low to moderate relief with few scattered laterite capped hills (Fig.3). The area shows a dendritic drainage pattern (Fig.4), and is drained by minor tributaries of the River Benue such as River Okpula and Owunobi, flowing almost parallel to one another. The drainage is topographically and structurally controlled.

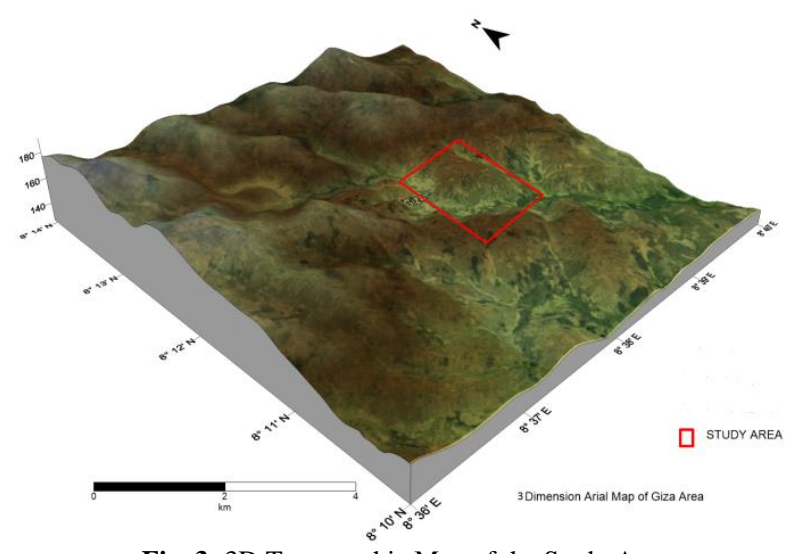

Fig. 3: 3D Topographic Map of the Study Area.

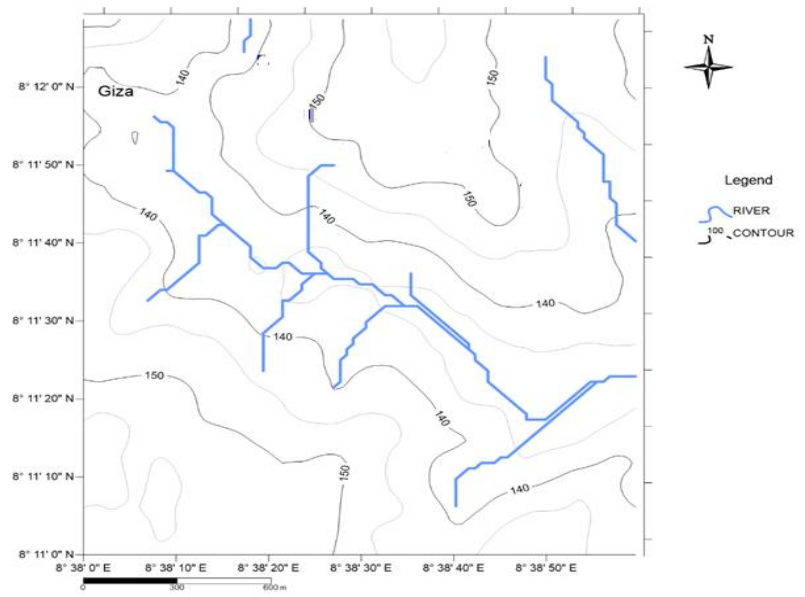

Fig. 4: Drainage Map of the Study Area.

\subsection{Geology of the study area}

The study area lies within the Central Benue Trough (CBT), which is composed of six stratigraphic successions believed to be Upper Cretaceous. These successions are Asu River Group, Ezeaku Formation, Keana Formation, Awe Formation, Awgu and Lafia Formations. The area is part of the Awgu formation (Fig.5), which is Late Turonian-Early Santonian in age, and lies comformably on the Ezeaku formation. Lithologically, it is made up of bluish-grey to dark-black carbonaceous shales, calcareous shales, shaleylimestones, limestones, sandstones, siltstones, and coal seams, the type locality outcrops at the bank of River Dep in Shankoli village. The peak of deposition of this formation was during the Late Turonian transgression, early Coniacian and terminated in early Santonian. This deposition marks the end of marine sedimentation in this part of the Benue Trough, with the Giza syncline, one the main fold elements (Offodile 1976). Obaje 2002, 2004; Nwajide, 1990 and Offodile, 1976 have worked extensively on the geology of the Central Benue Trough with emphasis on its economic geology and hydrogeology. 


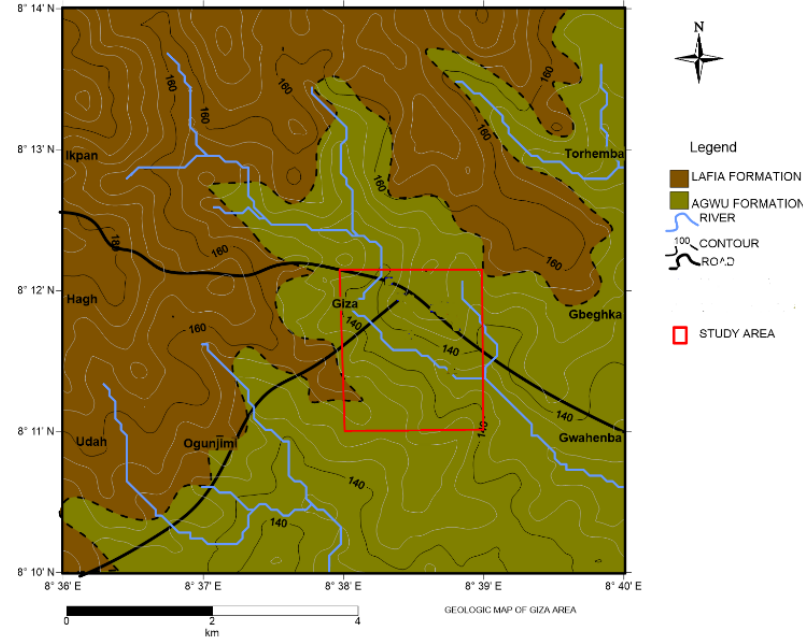

Fig.5: Geologic Map of the Study Area.

\subsection{Hydrogeology of the study area}

The hydrogeology of the Central Benue Trough was extensively studied by Offodile (2002), who reported that the hydrogeological situation of the valley is complex. He attributed the complexity to the fact that most potential aquifers are either limited in extent, thinly developed with clay and shale intercalations, which have poor water bearing and yielding capacity. He further noted that, because of the high indurated nature of the rocks, its hydrogeological potential depends on the development of secondary voids resulting from joints, fractures, and solution channel.

The aquifer of the Awgu Formation lies within the Sandstone beds of the formation. Where the sandstone are coarse grained, they are permeable and bear water. However, it is often limited in thickness and lateral extent, hence reducing the groundwater potential (Offodile, 2002). He studied a borehole of 150m deep within Awgu Formation and reported a yield of 0.3 litre/sec, and a static water level of $1.5 \mathrm{~m}$. The aquifer is the deepest, but with the least yield compared to Lafia and Awe Formations. The Awgu Formation which bears less water during the dry seasons covers areas like Daddare, Tudun Adabu and Giza.

\section{Methodology}

Static Water Levels (SWL) of hand dug wells and boreholes were measured during the wet and dry seasons, totaling fifty-seven in numbers. The water levels were measured using a SOLINT temperature, level, and conductivity (TLC) electric dip-meter. The lead of the electrical circuit is lowered into a well and as soon as the open lead touches water, the circle is completed, which is indicated by making a beep, and the reading from the calibrated tape is recorded. The depth in meters below sea level (mbsl), the elevations in meters above sea levels (masl) and coordinates (longitude and latitude) of the wells were also taken using Geographical Positioning System (GPS). The SWL measurements were carried out in the months of August and March for wet and dry season respectively. This was done very early in the morning when the water levels in the wells are not affected by withdrawal. These measurements were used to construct SWL contour map (Fig.6). SWL measurement of the wet season was subtracted from SWL measurement of dry season for each well to obtain the depth of fluctuation. SWL measurement (mbsl) was also subtracted from elevations (masl) for each well to obtain the groundwater elevations. The result was used to construct hydraulic head map, from which the direction of groundwater flow was determined (Fig.8).

\section{Results and discussions}

Groundwater levels for dry season varied between 5.5 and 13 mbsl (Table 1), and have a mean value of $7.8 \mathrm{mbsl}$. While the groundwater elevation in the dry season range from 131.8 to 157.2 masl.

Table 1: Static Water Level Measurement for Dry and Wet Season

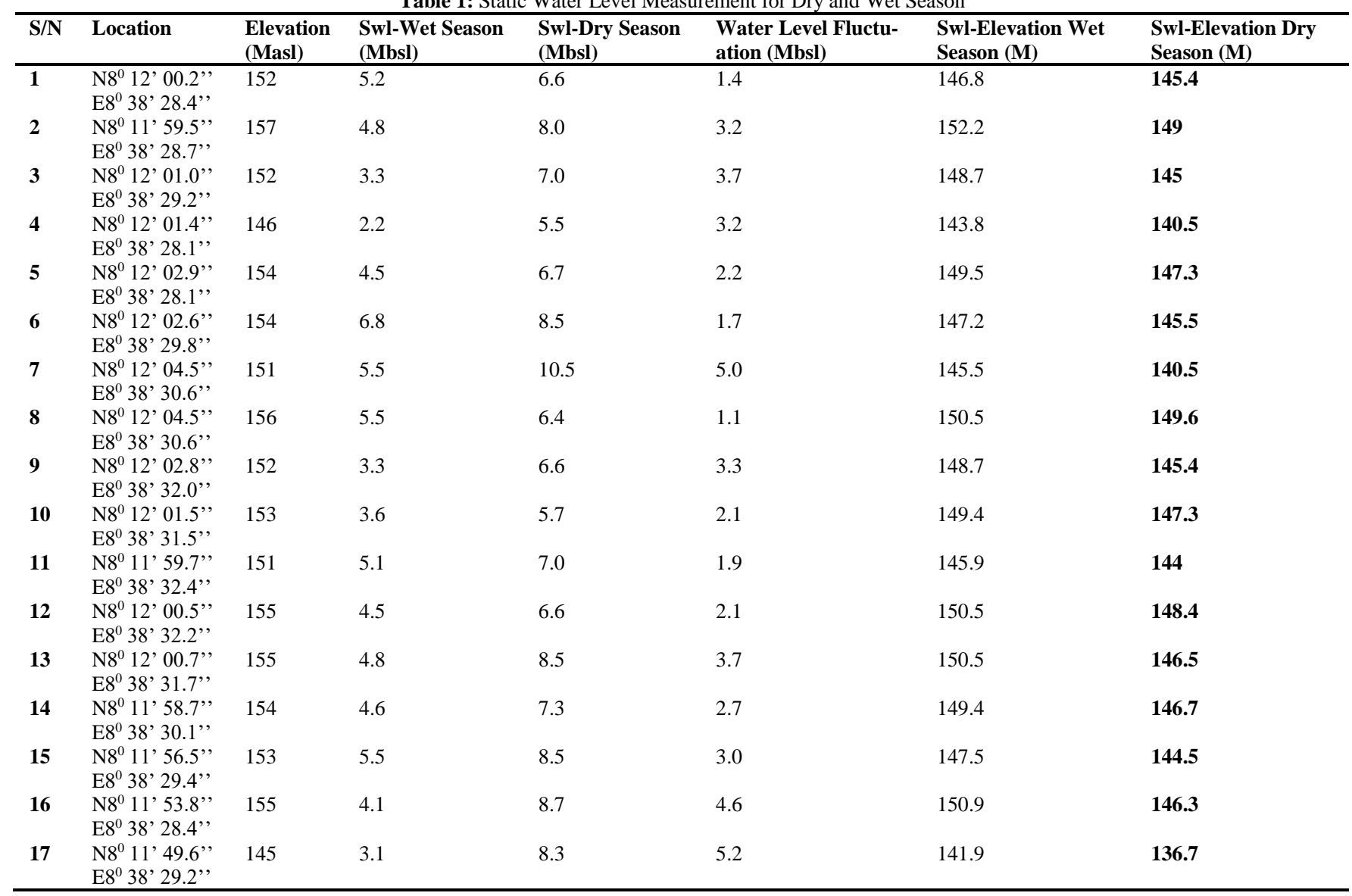




\begin{tabular}{|c|c|c|c|c|c|c|c|}
\hline 18 & $\begin{array}{l}\mathrm{N}^{0} 11^{\prime} 49.9^{\prime}, \\
\mathrm{E}^{0} 38^{\prime} 30.1,\end{array}$ & 160 & 3.5 & 9.4 & 5.9 & 156.5 & 150.6 \\
\hline 19 & $\begin{array}{l}\mathrm{N} 8^{0} 11^{\prime}, 49.5^{\prime}, \\
\mathrm{E}^{0} 38^{\prime} 30.1,\end{array}$ & 140 & 3.4 & 6.5 & 3.1 & 136.6 & 133.5 \\
\hline 20 & $\begin{array}{l}\mathrm{N} 8^{0} 11^{\prime}, 49.2^{\prime}, \\
\mathrm{E}^{0} 38^{\prime} 32.0\end{array}$ & 160 & 3.8 & 6.6 & 2.8 & 156.2 & 153.4 \\
\hline 21 & $\begin{array}{l}\mathrm{N} 8^{0} 11 ' 46.9^{\prime}, \\
\mathrm{E}^{0} 38^{\prime} 33.6,\end{array}$ & 139 & 3.0 & 7.2 & 4.2 & 136.0 & 131.8 \\
\hline 22 & $\begin{array}{l}\mathrm{N} 8^{0} 11^{\prime} 47.4^{\prime}, \\
\mathrm{E}^{0} 38^{\prime} 34.0\end{array}$ & 154 & 3.5 & 7.0 & 3.5 & 150.5 & 147 \\
\hline 23 & $\begin{array}{l}\mathrm{N} 8^{0} 11^{\prime}, 46.7^{\prime}, \\
\mathrm{E}^{0} 38^{\prime} 35.4^{\prime},\end{array}$ & 144 & 3.5 & 6.8 & 3.3 & 140.5 & 137.2 \\
\hline 24 & $\begin{array}{l}\mathrm{N} 8^{0} 11^{\prime}, 48.2^{\prime}, \\
\mathrm{E}^{0} 38^{\prime} \\
35.7^{\prime}\end{array}$ & 154 & 3.8 & 8.4 & 2.4 & 150.5 & 145.6 \\
\hline 25 & $\begin{array}{l}\mathrm{N} 8^{0} 11 ' 50.1, \\
\mathrm{E}^{0} 38^{\prime}, 34.3,\end{array}$ & 159 & 4.1 & 6.5 & 2.4 & 154.9 & 152.5 \\
\hline 26 & $\begin{array}{l}\mathrm{N} 8^{0} 111^{\prime}, 50.6, \\
\mathrm{E}^{0} 38^{\prime} \\
\end{array}$ & 146 & 4.3 & 6.7 & $2.4 \mathrm{~s}$ & 141.7 & 139.3 \\
\hline 27 & $\begin{array}{l}\mathrm{N} 8^{0} 11 ' 50.6^{\prime}, \\
\mathrm{E}^{0} 38^{\prime} 33.1,\end{array}$ & 165 & 4.5 & 8.0 & 3.5 & 160.5 & 157 \\
\hline 28 & $\begin{array}{l}\mathrm{N} 8^{0} 11^{\prime} 52.8^{\prime}, \\
\mathrm{E}^{0} 38^{\prime} 32.2^{\prime}\end{array}$ & 156 & 4.2 & 5.8 & 1.6 & 151.8 & 150.2 \\
\hline 29 & $\begin{array}{l}\mathrm{N} 8^{0} 11,55.8^{\prime}, \\
\mathrm{E}^{0} 38^{\prime} \\
29.1,\end{array}$ & 154 & 4.6 & 7.3 & 2.7 & 149.4 & 146.7 \\
\hline 30 & $\begin{array}{l}\mathrm{N} 8^{0} 11 ' 57.3^{\prime}, \\
\mathrm{E}^{0} 38^{\prime} 31.1,\end{array}$ & 145 & 5.5 & 9.3 & 3.8 & 139.5 & 135.7 \\
\hline 31 & $\begin{array}{l}\mathrm{N} 8^{0} 11,55.5, \\
\mathrm{E}^{0} 38^{\prime} 30.5,\end{array}$ & 152 & 4.7 & 7.5 & 2.8 & 147.3 & 144.5 \\
\hline 32 & $\begin{array}{l}\mathrm{N} 8^{0} 11^{\prime}, 54.9^{\prime}, \\
\mathrm{E}^{0} 38^{\prime} 30.5^{\prime}\end{array}$ & 147 & 4.4 & 6.3 & 1.9 & 142.6 & 140.7 \\
\hline 33 & $\begin{array}{l}\mathrm{N}^{0} 11 \\
\mathrm{E}^{0} 38^{\prime} \\
\end{array}$ & 151 & 4.1 & 6.8 & 2.7 & 146.9 & 144.2 \\
\hline 34 & $\begin{array}{l}\mathrm{N} 8^{0} 11 ' 56.8^{\prime}, \\
\mathrm{E}^{0} 38^{\prime} 31.2,\end{array}$ & 143 & 5.4 & 8.9 & 3.5 & 137.6 & 134.1 \\
\hline 35 & $\begin{array}{l}\mathrm{N} 8^{0} 11 ' 53.0, \\
\mathrm{E}^{0} 38^{\prime} 35.0,\end{array}$ & 146 & 4.7 & 9.1 & 4.4 & 141.3 & 136.9 \\
\hline 36 & $\begin{array}{l}\mathrm{N} 8^{0} 11 ' 52.2^{\prime}, \\
\mathrm{E}^{0} 38^{\prime} \\
\end{array}$ & 157 & 4.1 & 6.9 & 2.8 & 152.9 & 150.1 \\
\hline 37 & $\begin{array}{l}\mathrm{N}^{0} 11 \\
\mathrm{E}^{0} 38^{\prime} \\
\end{array}$ & 154 & 4.7 & 8.0 & 3.3 & 149.3 & 146 \\
\hline 38 & $\begin{array}{l}\mathrm{N} 8^{0} 11 ' 53.8^{\prime}, \\
\mathrm{E}^{0} 38^{\prime} 36.1,\end{array}$ & 152 & 5.1 & 7.6 & 2.5 & 146.9 & 144.4 \\
\hline 39 & $\begin{array}{l}\mathrm{N} 8^{0} 11^{\prime}, 49.7^{\prime}, \\
\mathrm{E}^{0} 38^{\prime} 38.3,\end{array}$ & 155 & 4.5 & 8.6 & 4.1 & 150.5 & 146.4 \\
\hline 40 & $\begin{array}{l}\mathrm{N} 8^{0} 11 ' 52.2^{\prime}, \\
\mathrm{E}^{0} 38^{\prime} \\
\end{array}$ & 150 & 5.4 & 9.3 & 3.9 & 144.6 & 140.7 \\
\hline 41 & $\begin{array}{l}\mathrm{N} 8^{0} 11 ' 51.8^{\prime}, \\
\mathrm{E}^{0} 38^{\prime}, 40.2,\end{array}$ & 148 & 8.0 & 11.5 & 3.5 & 140.0 & 136.5 \\
\hline 42 & $\begin{array}{l}\mathrm{N} 8^{0} 11^{\prime}, 52.0^{\prime}, \\
\mathrm{E}^{0} 38^{\prime} \\
41.2,\end{array}$ & 151 & 9.2 & 13 & 3.8 & 141.8 & 138 \\
\hline 43 & $\begin{array}{l}\mathrm{N} 8^{0} 11^{\prime}, 46.0 \\
\mathrm{E}^{0} 38^{\prime}, 40.6\end{array}$ & 152 & 4.1 & 6.7 & 2.6 & 147.9 & 145.3 \\
\hline 44 & $\begin{array}{l}\mathrm{N} 8^{0} 11^{\prime}, 44.4^{\prime}, \\
\mathrm{E}^{0} 38^{\prime}, 44.3\end{array}$ & 150 & 4.6 & 8.2 & 3.6 & 145.4 & 141.8 \\
\hline 45 & $\begin{array}{l}\mathrm{N} 8^{0} 11^{\prime} 44.6^{\prime}, \\
\mathrm{E} 8^{0} 38^{\prime} 44.3,\end{array}$ & 152 & 6.3 & 9.8 & 3.5 & 145.7 & 142.2 \\
\hline 46 & $\begin{array}{l}\mathrm{N}^{0} 11^{\prime}, 44.9^{\prime}, \\
\mathrm{E}^{0} 38^{\prime}, 41.8^{\prime}\end{array}$ & 155 & 3.7 & 6.8 & 3.1 & 151.3 & 148.2 \\
\hline 47 & $\begin{array}{l}\mathrm{N} 8^{0} 11,59.3^{\prime}, \\
\mathrm{E}^{0} 38^{\prime}, 40.5\end{array}$ & 163 & 5.0 & 9.2 & 4.2 & 158.0 & 153.8 \\
\hline 48 & $\begin{array}{l}\mathrm{N}^{0} 11 \\
\mathrm{E}^{0} 38^{\prime} \\
\end{array}$ & 163 & 5.2 & 7.3 & 2.1 & 157.8 & 153.8 \\
\hline 49 & $\begin{array}{l}\mathrm{N} 8^{0} 11^{\prime}, 59.4^{\prime}, \\
\mathrm{E}^{0} 38^{\prime} \\
38.2,\end{array}$ & 154 & 5.5 & 6.9 & 1.4 & 148.5 & 147.1 \\
\hline 50 & $\begin{array}{l}\mathrm{N} 8^{0} 12^{\prime}, 00.9^{\prime}, \\
\mathrm{E}^{0} 38^{\prime} \\
37.1\end{array}$ & 159 & 6.3 & 8.1 & 1.8 & 152.7 & 150.9 \\
\hline 51 & $\begin{array}{l}\mathrm{N}^{0} 12^{\prime}, 00.8^{\prime}, \\
\mathrm{E}^{0} 38^{\prime} 35.6^{\prime}\end{array}$ & 160 & 4.4 & 6.6 & 2.2 & 155.6 & 153.4 \\
\hline 52 & $\begin{array}{l}\mathrm{N} 8^{0} 12^{\prime} 00.1^{\prime}, \\
\mathrm{E}^{0} 38^{\prime} 36.4^{\prime},\end{array}$ & 162 & 5.3 & 10 & 4.7 & 156.7 & 152 \\
\hline 53 & $\begin{array}{l}\mathrm{N} 8^{0} 11 ' 59.6, \\
\mathrm{E}^{0} 38^{\prime} \\
\end{array}$ & 161 & 5.5 & 8.4 & 2.9 & 155.5 & 152.6 \\
\hline 54 & $\begin{array}{l}\mathrm{N} 8^{0} 11 ' 59.5^{\prime}, \\
\mathrm{E}^{0} 38^{\prime} 35.0,\end{array}$ & 165 & 5.0 & 7.8 & 2.8 & 160 & 157.2 \\
\hline 55 & $\begin{array}{l}\mathrm{N}^{0} 11 \\
\mathrm{E}^{0} 38^{\prime} \\
\text { ' } 38.4^{\prime},\end{array}$ & 165 & 5.4 & 9 & 5.4 & 159.6 & 156 \\
\hline 56 & $\begin{array}{l}\mathrm{N} 8^{0} 11^{\prime}, 57.7^{\prime}, \\
\mathrm{E}^{0} 38^{\prime} 35.3^{\prime},\end{array}$ & 161 & 5.3 & 6.5 & 5.3 & 155.7 & 154.5 \\
\hline 57 & $\begin{array}{l}\mathrm{N8}^{0} \text { 11' } 56.7^{\prime}, \\
\text { E8 }^{0} 38^{\prime} 34.8^{\prime},\end{array}$ & 163 & 5.3 & 8.2 & 5.3 & 157.7 & 154.8 \\
\hline
\end{tabular}


Wet season records a peak level of $2.2 \mathrm{mbsl}$ and deepest level of $9.2 \mathrm{mbsl}$, with a mean of $4.7 \mathrm{mbsl}$. The groundwater elevations for this season range from136 to 160 masl (Table 1).The depth of groundwater level fluctuation lies between 1.1 to 5.9 mbsl (Table 1). Static water levels (SWL) in the dry season are deeper than that of wet season, while the groundwater elevation is higher in wet season than dry season. Groundwater levels in the study area were observed to vary from one season to the other and from one location to another. The high water levels in wet season are as a result of recharge exceeding discharge, as water in storage will increase and raises the water levels. During the dry season, discharge and evapo-transpiration exceeds recharge, decreasing the water in storage and lowering the water levels. The variation in groundwater levels can be attributed to differences in rechargestorage-discharge, change in topography, groundwater withdrawal, stream stage and aquifer's hydraulic characteristics. Wells in the study area showed a direct rapid response to short term seasonal precipitation, according to Chen et al. (2004) is one of the effects of climate change on groundwater. This is because groundwater occurs at shallow depth, which is characteristic of poorly unconfined aquifer.

Groundwater in the study area flow perpendicular to the water level contours (Fig.7) and from higher topography to the lowlaying areas (Fig.3). This corresponds to the northern and other parts (recharge areas) towards the southern part (discharge area) At the recharge areas, the static water levels are deeper from the ground surface compared to the static water levels at the discharge area.

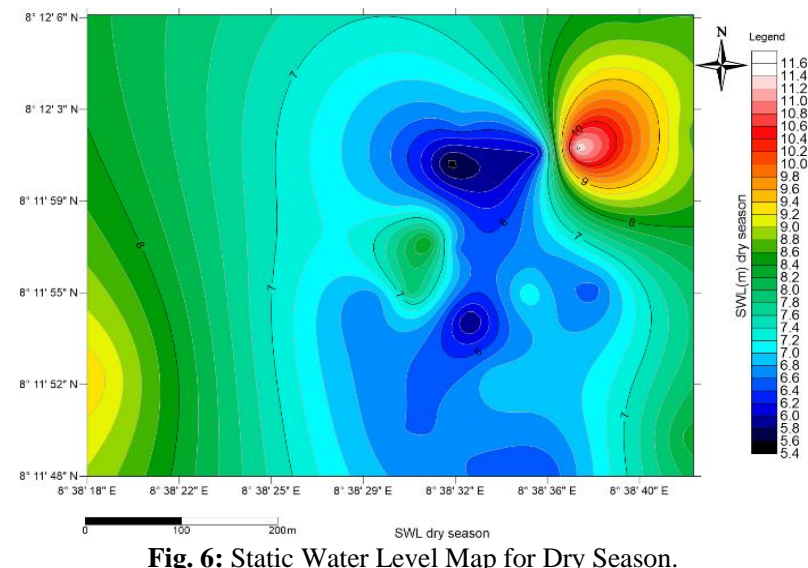

Fig. 6: Static Water Level Map for Dry Season.

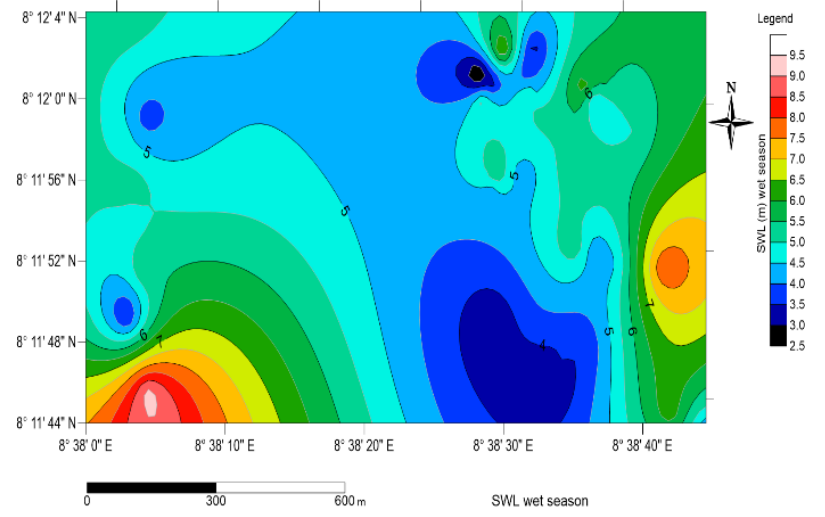

Fig. 7: Static Water Level Map for Wet Season.

\subsection{Geophysical investigations}

Result of the geophysical investigation (Table 2) showed that the study area is underlain by four geoelectric layers VES 1 is composed of top soil, sandy-clay, clay and shale having resistivity of $160 \Omega \mathrm{m}, 1.03 \Omega \mathrm{m}, 13.9 \Omega \mathrm{m}, 19.3 \Omega \mathrm{m}$ and thickness of $0.46 \mathrm{~m}, 39.6 \mathrm{~m}$, and $13.6 \mathrm{~m}$ respectively. VES 2 and VES 3 showed similar stratigraphy; loose top soil of be- tween 0.5 and $1.2 \mathrm{~m}$ thick having resistivity range of 20.8 to $49.12 \Omega \mathrm{m}$, overlaying clay of 0.95 to $3.60 \mathrm{~m}$ thick with low resistivity between 16.5 and $16.25 \Omega \mathrm{m}$, underlain by saturatedclay of 10.88 to $16.21 \mathrm{~m}$ thickness, with resistivity range of 1.62 to $1.18 \Omega \mathrm{m}$, overlaying shale of infinite depth. VES4 revealed compact top soil, sand, clay and shale having thickness and resistivity of $0.68 \mathrm{~m}, 1.5 \mathrm{~m}, 19.8 \mathrm{~m}, \infty$ and $211 \Omega \mathrm{m}$, $71.4 \Omega \mathrm{m}, 11 \Omega \mathrm{m}, 5.9 \Omega \mathrm{m}$ respectively.

Table 2: Geophysical Investigations Results

\begin{tabular}{llllll}
\multicolumn{6}{c}{ Table 2: Geophysical Investigations Results } \\
\hline VES & Layers & $\begin{array}{l}\text { Resistivity } \\
(\Omega \mathrm{m})\end{array}$ & Thickness & Depth & $\begin{array}{l}\text { Inferred Lithol- } \\
\text { ogy }\end{array}$ \\
\hline 1 & $\rho_{1}$ & 160 & 0.46 & 0.46 & Topsoil/Laterite \\
& $\rho_{2}$ & 39.6 & 1.03 & 1.49 & Sandy-Clay \\
& $\rho_{3}$ & 13.9 & 13.60 & 14.53 & Clay \\
& $\rho_{4}$ & 19.3 & $\infty$ & Shale \\
2 & $\rho_{1}$ & 20.8 & 0.50 & 0.5 & Loose top soil \\
& $\rho_{2}$ & 16.5 & 0.95 & 1.0 & Clay \\
& $\rho_{3}$ & 1.62 & 10.88 & 11.88 & Saturated-Clay \\
& $\rho_{4}$ & 20.5 & $\infty$ & & Shale \\
3 & $\rho_{1}$ & 49.12 & 1.20 & 1.2 & Loose top soil \\
& $\rho_{2}$ & 16.25 & 3.60 & 4.8 & Clay \\
& $\rho_{3}$ & 1.18 & 16.21 & 21.10 & Saturated-Clay \\
& $\rho_{4}$ & 27.94 & $\infty$ & & Shale \\
4 & $\rho_{1}$ & 211 & 0.68 & 0.68 & Compact top \\
& $\rho_{2}$ & 71.4 & 1.5 & 2.90 & Soil \\
& $\rho_{3}$ & 11 & 19.8 & 22.70 & Clay \\
& $\boldsymbol{\rho}_{4}$ & 5.9 & $\infty$ & & Shale \\
\hline
\end{tabular}

\subsection{Geotechnical implications}

Establishing the highest and lowest groundwater level is very important in the design and construction of engineering structures Arora (2004), Idris and Igwe (2018). The geotechnical implication of groundwater fluctuation is that excess pore water pressure may develop under foundations (Collison et al. 2000) reducing shear strength and causing distress on engineering structures such as buildings and pavements. In and around VES1, foundations are underlain by sandy-clay. Foundations around VES2 and VES3 are laid on clays, while VES4 revealed sand as the underlain lithology. Foundations around VES1 will be relatively stable compared to foundations around VES2 and VES3 which will be saturated as water level rises and dry up as water level drops due to poor drainage. Moisture content fluctuation in clays is responsible for the formation of expansive minerals, which causes shrink-swell behavior. Shrink-swell behavior leads to subsidence, foundation heave, differential settlement, tilt, development of cracks along doors and windows and even collapse in severe cases which will affect the serviceability of engineering structures. Foundations around VES4, is expected to be more stable, this is because even as water level rises, sands have good permeability which will permits drainage. The water is dissipated, therefore preventing excess pore water pressure and significantly increasing shear strength.

About $78.9 \%$ of the area has a shallow zone of fluctuation around 1.1 to $3.7 \mathrm{~m}$, while $21.1 \%$ of the area has deeper zone of fluctuation ranging between 4.6 and $5.6 \mathrm{~m}$. Considering that most foundations within the study area are shallow usually between 1.5 to $3.0 \mathrm{~m}$, cyclic wetting and drying will take place especially in areas underlain by clays. Volume changes are generally greatest near the surface and decreases with increasing depth. The ultimate bearing capacity of foundation is affected by the depth of footing in relation to the water table.

For mega engineering structures, especially around the areas underlain by clays, foundations should be placed on pile, which will transfer the load to a more competent layer. 


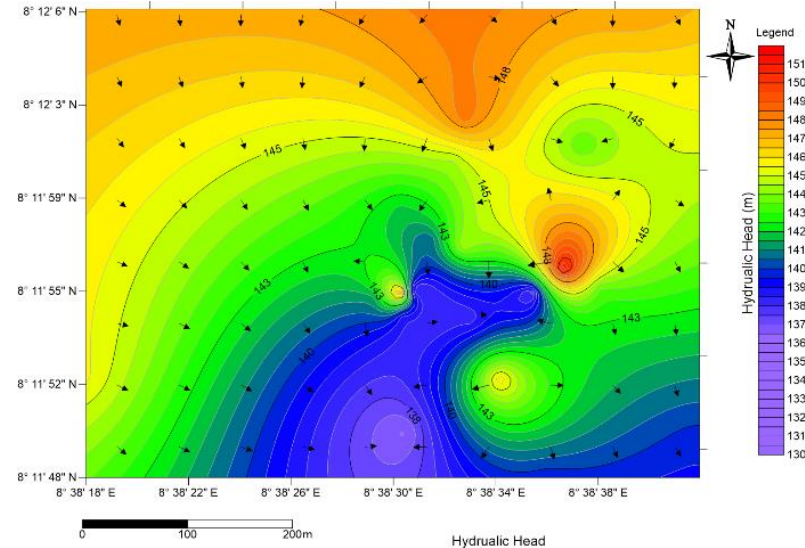

Fig. 8: Groundwater Configuration Map Showing Flow Direction.

\section{Conclusion}

The localized impact of climatic variation (seasonal change) on groundwater fluctuation was studied. Generally, wells in the study area showed a direct rapid response to short term seasonal precipitation (climatic variation), which is a characteristic of poorly unconfined aquifer. Groundwater level fluctuation ranges between 1.1 and $5.9 \mathrm{mbsl}$. The change in groundwater levels is caused by factors relating to climate variation such as change in temperature, infiltration and precipitation which affects well's recharge, storage, and discharge.

Foundations in the study area are underlain by sandy-clays, clays and sands, which are considered moderately competent, incompetent and competent foundation materials respectively. Due to the shallow zone of groundwater fluctuation and the thickness of the clayey layer $(1.1 \mathrm{mbsl}$ and $0.95 \mathrm{~m})$, soils around these sites will undergo cyclic swelling and shrinking as water level rises and falls. This implies that foundations built on the clays may experience cracks, settlement, tilt, and partial or complete collapse. However, foundations built on the sandy parts of the study area will be relatively stable due to high permeability which allows drainage. Foundations in the clayey areas should be placed beyond the depth of groundwater fluctuation.

\section{Acknowledgement}

The authors wish to sincerely appreciate the staff and management of Lifewaters and Associates Ltd. for their support with equipment and personnel in carrying out the SWL measurement and the geophysical survey investigations.

\section{References}

[1] Apaydin A (2009) Response of groundwater to climate variation: fluctuations of groundwater level and well yields in the Halacliaquifer (Cankiri, Turkey). Enviromental Monitoring and Assessment 165, 653-663. https://doi.org/10.1007/s10661-009-0976-8.

[2] Alexandra SR, Thomas BF, Lo M-H, Reager JT (2015) Quantifying Renewable Groundwater Stress with Grace.51, 5217-5238. https://doi.org/10.1002/2015WR017349.

[3] Bell FG (2007) Engineering Geology, 2nd edn. Elsevier: London, UK. Pp. 207-248.

[4] Changnon SA, Huff FA, Hsu CF (1988) Relations between precipitation and shallow groundwater in Illinois. Journal of Climate, 1 1239-1250. Doi: 10.1175/1520-0442.

[5] Chen Z, Grasby SE, Osadetz KG (2004) Relation between climate variability and groundwater levels in the upper carbonate aquifer, southern Manitoba, Canada. Journal of Hydrology, 290, 43-62. https://doi.org/10.1016/j.jhydrol.2003.11.029.

[6] Collison A, Wade S, Griffiths J, Dehn M (2000) Modelling the impact of predicted climate change on landslide frequency and magnitude in SE England. Engineering Geology, 55, 205-218.

[7] Idris IG, Igwe O (2018) Assessment of Foundation Instability Using Integrated Techniques: A case study of Giza, Keana LGA, Na- sarawa State, Northcentral Nigeria. American Scientific Reseach Journal for Engineering, Technology, and Sciences. 41, 85 - 108.

[8] Nwajide CS (1990) Crataceous sedimentation and paleogeography of the Central BenueTrough. Vieweg and Sohn, Germany.

[9] Offodile ME (1976) The Geology of Middle Benue Trough, Nigeria paleontological Instituteof the University of Uppsala special 4.

[10] Offodile ME (2002) an approach to groundwater study and development in Nigeria $2^{\text {nd }}$ Edition Mecon Publishing p. 240

[11] Sang-Ki M, Woo NC, Lee KS (2003) Statistical analysis of hydrographs and water table fluctuation to estimate groundwater recharge. Journal of Hydrology; 292, 198-209.

[12] Tahir AG, Garba I, Garba ML (2016) Seasonal Ground water Configuration Maps showing Water level in Kano Metropolis, Nigeria. Dutse Journal of Pure and Applied Sciences.

[13] Umar ND (2014) A Hydrochemical Study of the Brine Fields of Awe, Keana and Giza Areas,Middle Benue Trough, Nigeria. Msc. Thesis, University of Nigeria, Nsukka.

[14] Zektser IS, Loaiciga HJ (1993) Groundwater fluxesin the global hydrologic cycle past, present, and future. Journal of Hydrology (Amsterdam),144, 405-442.doi:10.1016/0022-1694 (93)90182-9. 